\title{
VANUATU Republic of Vanuatu
}

\author{
Area: 14,760 sq. km \\ Population: 117,000 \\ Capital: Vila
}

Prime Minister: Walter Hadye Lini

Minister of Home Affairs: S. Regenvanu

Vanuatu, has been independent since July 1980. It was formerly known as the Condominium of the New Hebrides. It consists of 13 large and about 70 small islands. The New Hebrides Constabulary was formed in 1914 and for a time had a dual command - two Resident Commissioners, one British (an officer of the HM Overseas Police Service) and one French (an officer of the Gendarmerie d'Outremer), each in charge of a Police Division.

There is a small police force, a legacy of pre-independence days. It includes a Criminal Investigation Department, a Special Branch for internal security duties, and its own barracks for unmarried personnel. Headquarters is at Vila, and there are police detachments at the district agencies on the islands of Malekula, Santo and Tanna. Training is conducted at Honiara (Solomon Islands) and at the Gendarmerie School at Noumea (French New Caledonia).

The paramilitary Militia (Milice) is available to cope with civil disturbances. There is no army.

Police Station/Commissariat de Police, Vila (2252, 2333) 